\title{
A STUDY OF THE INVESTMENT BEHAVIOR BASED ON BEHAVIORAL FINANCE
}

\author{
Yu Zhang', Xiaosong Zheng" \\ ${ }^{1}$ Shanghai University, Shanghai, China \\ 1,2 Tallinn University of Technology, Tallinn, Estonia
}

\section{ABSTRACT}

Behavior finance introduces psychology, sociology and other research methods into the study of investment behavior to explain how investors handle the information and take actions. This paper presents the literatures as theoretical solutions to the market anomalies of the traditional market theories. The behavioral psychology is examined through the study on the questionnaire of Chinese security investors. The results show that the investors are not always adopt rational behaviors as traditional finance theory assumed, but make a lot of irrational decisions based on individual cognitive and prejudices, even institutional investors often show the characteristic of irrational. In the guidance of the behavioral finance theory, the research will be closer to the reality and give more significant insight to the selection of investment strategy and psychology characteristic used to explain market anomalies.

\section{JEL CLASSIFICATION \& KEYWORDS}

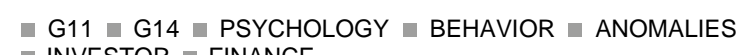
- INVESTOR = FINANCE

\section{INTRODUCTION}

The behavior of security investors is assumed to be rational based on traditional finance theory. And as per this concept, a series of theories are formed such as Efficient Market Hypothesis (EMH), Capital Asset Pricing Model (CAPM), Portfolio theory, Two-fund separation theorem (MM), etc. However, consistent support comes with various arguments in recent years. For example, the benefits of diversified investing are emphasized by traditional theories, while still a few stocks are hold in portfolios by individual investors. Traditional finance theory considers rational investors can seize the opportunities created by irrational ones to survive and occupy the whole security market, while some empirical researches and abnormal phenomenon such as momentum effect, winner-loser effect, Friedman-Savage Puzzle and riddle of bonus bring challenge to it. As psychologists and sociologists have found their way into finance in the last decade, economic agents are also no longer to be assumed as rational actors. Instead, they are normal human beings with faults and cognitive foibles including emotional responses, reference points, overconfidence, positive illusion, loss aversion, framing, confirmatory bias, outcome bias, hindsight bias and so on, causing the emergence of behavioral finance (Jones, 2012).

Being described as contradictory to much of traditional market theory, Shiller illustrated finance from a broader human and social perspective, including sociology and psychology. Since 1990s, the focus on traditional asset pricing model has shifted towards new models incorporating psychology (Patrick \& Charles, 2011). The editor of Journal 은 of Behavioral Finance, previously naming Journal of

\footnotetext{
'395401095@qq.com

"xiaosong.zheng@shu.edu.cn
}

www.journals.cz
Psychology and Financial Markets, pointed out that the importance of social behaviors and human cognition is prompted by behavioral finance theory.

Sent (2004) pointed out that the success and prevalence of behavioral finance attribute to its efficient availability of data and testable predictions compared with traditional efficiency market theory, thus revealing that learning, arbitrage and evolution do not eliminate complications and human limitation. More meaningful thing is to use behavioral finance theory as a mirror to find blemishes of ourselves rather than just a magnifying glass to research the biases of others (Jones, 2012).

Under the condition of Chinese security market's short development and China's special system, the investors' irrational performance is more noticeable, irrational psychology and behavior will have a long-term, substantial effect on the entire market. Therefore, behavioral finance theory is not applicable in terms of analyzing the behaviors of Chinese security investors.

\section{Literature review}

Several influential theories have been prompted by behavioral finance theory through the study on investor psychology, which can be used to explain market anomalies to some extent.

\section{Heuristics bias}

Several influential theories had been prompted by behavioral finance theory through the study on the psychology of investors, which can be used to explain market anomalies to some extent.

Three common heuristics (representativeness, availability, and adjustment and anchoring) were identified by Kahneman \& Tversky (1974) as systematic biases in investment-decision judgment. Patrick \& Charles (2011) argued that people often rely on rules of thumb or heuristics rather than rational analysis to evaluate risks in face of uncertainty. Trivers $(1985 ; 1991)$ also pointed out that the true internal states cannot perfectly controlled by irrational investors.

Representativeness refers to that $A$ represent $B$ through assessed possibilities, which A resembles B (Patrick \& Charles, 2011). Tversky \& Kahneman (1974) pointed out that representative heuristics would prompt two main biases; one of them is the ignorance of the prior probabilities the sample is drawn because of over-emphasis on one characteristic. The ignorance of the significance of the size of the sample is the other bias, resulting in obtaining conclusion on the basis of little data, which is called Gambler's Fallacy effect by Rabin (1999).

Andreassen \& Kraus (1990) found that subjects tend to buy on dips while sell on rises when the price fluctuates, which is in consistence with gambler's fallacy. Andreassen \& Kraus (1990) also provided evidence to show that this kind of trick is less used by the subjects who would prefer chasing trends 


\section{A STUDY OF THE INVESTMENT BEHAVIOR BASED ON BEHAVIORAL FINANCE}

when an obvious trend appears. De Bondt \& Thaler (1985) argued that investors are prone to believe the continuousness of past situation, over-pessimistic on loser and over-optimistic on winner, causing the deviation from true value of stocks.

Availability bias means that people tend to assess the probability of an event based on the recalled past event rather than actual data collection (Patrick \& Charles, 2011). Tversky \& Kahneman (1974) pointed out that investors would predicate higher probability of upward tendency of a stock on account of the media publicity. According to Fischhoff, Slovic, \& Lichtenstein (1978), people often undervalue the possibility of an indirect or invisible event. Overreaction and overconfidence can be suggested when unforeseen events occur (Hirshleifer, 2001). Shiller (1984) also argued that the focus of attention of investors can be unsteady and easily changed by other people, especially alleged experts.

Anchoring and Adjustment bias describes the investors who usually reduce ambiguous with some reference points and reach a conclusion through appropriate adjustment (Liu, 2006). Patrick and Charles (2011) stated that investors with this bias would like to assume the rough correct of stocks' current price, resulting in certain predictability biases. Lovric (2008) pointed out that the adjustment of this heuristic bias is always insufficient which will cause overreliance on the anchor price. Shefrin (2000) argued that security analysts often being conservative and slowly adjust to the new information. Tversky \& Kahneman (1974) also found that people tend to be constrained by meaningless "initial anchor".

\section{Cognitive bias}

Typical cognitive bias include over-confidence, over-reaction and herd effect.

Over-confidence refers to people over-evaluate the probability of success and accurate of private information (Liu, 2006). Numerous literatures indicate that people often believe their knowledge is broader than it really is. For example, Alpert \& Raiffa (1982) argued that the confidence interval of $98 \%$ contain the really quantity of only $60 \%$. Griffin \& Tversky (1992) stated that experts tend to be more overconfidence than ordinary investors when evidence is ambiguous and predictability is low. Kahneman \& Reiepr (1998) confirmed that investors would like to narrow margin of error on future stock index under the influence of overconfidence. De Bondt \& Thaler (1995) also pointed out that over-confidence may be one of the steadiest human psychologies, which causes biased assessment on uncertainty events.

Over-reaction is a common phenomenon that investors over-weight information as a result of irrational bias $(\mathrm{Wu}$, 2004). Russell (2000) found that at least $10 \%$ of investor over-reaction when making decision. De Bondt \& Thaler (1985) conducted an in-depth study on over-reaction in the article "Does the stock market overreact?" and argued that investors are not as rational as assumed, instead, they often overestimate new information and ignore long-term information. In contrast, institutional investors are tend to be under-reaction, which means they are usually confident a their judgment and don't change their minds easily.

Herd behavior is a special irrational behavior which illustrates the psychology of investors imitating others investment decision and over-relying on public opinion without consideration of their own information. Lakonishok, Shleifer, \& Vishny (1992) defined herd effect as investors buy or sell stocks at the same time with other investors. Scharfstein \& Stein (1990) pointed out that herd effect will impact the efficiency of security market, causing the fluctuation of stocks' price.

\section{Objectives and Methodology}

\section{Objectives}

Behavioral finance theory has explained some anomalies of traditional finance theory through several psychology biases of investors. In order to further examine the existence and significance of these behavioral psychology biases, the paper selects four typical ones to analyze. This paper can also help ordinary and institutional investors recognize their psychology biases and improve investment accordingly.

\section{Methodology}

The paper analyses quantitative data to conduct descriptive study. Sekaran (2003) pointed out that the descriptive study can explain the features of the variables. Moreover, a survey questionnaire with predetermined questions implemented by Dong is applied to study the behavior of Chinese investors) with the survey sample clients being selected from20 sales departments of Southwest Securities, Northwest Securities, Huatai Securities, Hantang Securities, United Securities and so on (Dong, 2003).

Stratified random sampling method is used (institutional and ordinary investors are divided according to the transaction amount), 1000 survey questionnaires are given out randomly and collected back on time. $95 \%$ of all questionnaires are issued to ordinary investors, and $5 \%$ to institutional investors with 623 and 37 pieces of effective questionnaires respectively. The method of data collection is self-administered questionnaires containing predetermined questions to enable researchers to get results easier and quicker. Sekaran (2003) argued that personally administer the questionnaires is a good choice when conducting the survey in a local area. Lower cost and faster speed are two main reasons to choose questionnaire as research method.

\section{Results and Discussion}

\section{Conservative bias}

Obvious conservative bias among Chinese security investors is reflected through two aspects.

When the stocks with ordinary performance suddenly receive excessive returns, $61.99 \%$ of Chinese investors choose to sell at opportune moment while only $39.57 \%$ prefer buy in additionally. In terms of institutional investors, $70.82 \%$ choose to sell and 29.16 to buy in. (II) In face of new information, $42 \%$ of ordinary investors would require further confirmation rather than make use of it immediately $(21.33 \%)$. Institutional investors show more preference on further confirmation ( $58.33 \%$ compared with only $8.33 \%$ ) (see Tab. 1).

Different proportion on these two questions indicates various expected return in the future and extent of conservation. Obviously, institutional investors have more conservative bias than ordinary investors in China. The phenomenon of conservatism is identified by Edwards in 1968 that individuals are not prone to change their beliefs as a rational Bayesian under new information. Edwards (1968) also argued that the more useful the new information, the larger the difference between rational updating and actual updating. Grether (1992) pointed out that different judgments can be made in different situations according to experimental evidence, showing various kind of conservatism. 


\section{A STUDY OF THE INVESTMENT BEHAVIOR BASED ON BEHAVIORAL FINANCE}

The people who choose to sell the good-performance stock are more than twice the time as ones who keep holding it. This reveals the psychology that investors tend to hold certain profit rather than chase more dubious return. More investors in China are small-to-medium retail investors who are prone to engage in short-term investment, which means once the stock have excess return, they will sell it to get certain return.

Hirshleifer (2001) argued that one of the explanations fo conservatism is that conducting new evidence and updating opinion is costly and people may be under-react to new evidence. The phenomenon of under-reaction is more evident among experts as half of them would not like to incorporate new information into their investment strategy and think it needs further consideration. Conservative bias can be one of the most typical opposed evidences for market efficiency theory as prices will not effectively reflect market information.

\section{Over confidence}

According to the research figure, half of ordinary investors consider own judgment as correct and $20.86 \%$ obtain higher return from their own judgment. Ones who are not sure about their judgment account for $22.18 \%$ while only $6.95 \%$ admit the mistakes they have made. Institutional investors are even more confident than ordinary investors, respectively $52 \%, 40 \%$, and $8 \%$ of them regard their judgment as correct, not sure and wrong. Furthermore investors who think themselves as talented represent $79.07 \%$, compared with $20.93 \%$ who consider the opposite. The figures among institutional investors are $96 \%$ and only $4 \%$ hold the opinion of untalented (see Table 1).

Obvious characteristic of over confidence of Chinese security investors can be seen from the above two questions and institutional investors are more confident than ordinary investors. According to numerous research and literatures, investors tend to overrate their judgment, which can cause biased evaluation. It is interesting to note that almost all of institutional investors consider themselves as talented people, resulting in half of them believe the accurate of their strategy. Scheinkman and Xiong (2003) argued that institutional investors would like to buy overvalued stocks when they have positive information as they are confident to sell them to people of more extreme beliefs. However, in face of uncertainty, over-confidence may cause the abnormal change of stock price, especially as institutional investors hold a large amount of fund, which can influence the trend of stocks in finance market.

In terms of another angle of view, Bernardo \& Welch (2001) argued that overconfidence of investors can contribute to the emergence of new ideas, which is beneficial to economy and finance market.

\section{Self-attribution bias}

When contradiction exists between the fact and own judgment, $58.27 \%$ ordinary investors believe that the situation is ambiguous and more time is necessary to examine the results, $22.18 \%$ of them even insist the origina judgment and only $19.53 \%$ admit the mistake of original judgment. However, if the fact is consistent with judgment $36.45 \%$ attribute it to their own judgment ability. This bias is more obvious among institutional investors with success self-attribution accounts for $72 \%$ and $64 \%$ unwilling to attribute inconsistent to fault judgment (see Tab. 1).

The characteristic of self-attribution can be seen from the statistic figure. People, especially institutional investors, are more prone to attribute good results to own abilities and bad results to external reasons (Hirshleifer, 2001). Selfattribution and overconfidence can attribute to similar psychology of investors as they over-believe in the correctness of their investment strategy. Hirshleifer (2001) also argued that self-attribution and overconfidence are dynamic and static counterparts; self-attribution lead to overconfidence instead of converging to the actual selfevaluation.

\section{Loss aversion}

Regarding a gamble from which you can win $\$ 200$ and loss $\$ 100$ at equal possibilities. $42.86 \%$ ordinary investors and $37.83 \%$ institutional investors are unwilling to take part in. However, as the repeat number of gamble increase to 100 times, $88.92 \%$ and $91.89 \%$ investors would like to conduct the gamble (see Table 1).

Another interesting comparison is, when the bet of the gamble is to win and loss $\$ 100$ at equal possibilities, $35.63 \%$ ordinary and $32.43 \%$ institutional investors would like to accept it while if the bet increases to $\$ 10000$, only $18.94 \%$ and $18.91 \%$ investors would like to accept it.

The psychology of loss aversion can be seen from the above comparisons. Hirshleifer (2001) defined that loss aversion is the phenomenon that people are prone to avoid risks that relative to a reference point in the utility function. Samuelson (1963) pointed out that for the choice of a single gambling that near the reference point, quite a few people tend to reject the gamble with the fear of the loss of $\$ 100$ although the gamble have obvious benefits. However, the selection is far from the reference point when the gamble can be repeated 100 times, so most people chose to accept the gamble (Samuelson, 1963). Barberis \& Huang (2001) examined that loss aversion can result in excess fluctuation in stock prices. Barberis (2001) pointed out that loss aversion bias can help explain equity premiun puzzle as investors require a high premium to long-term hold stocks. Moreover, Grinblatt \& Han (2005) stated that momentum effect can also be explained by loss aversion psychology.

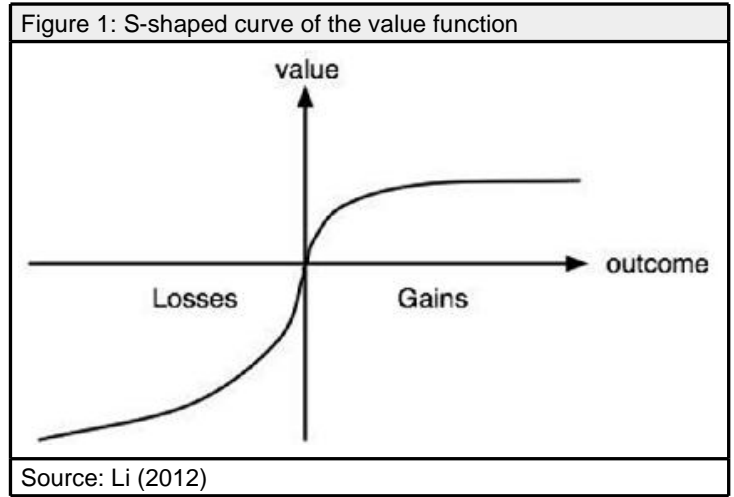

The value function (see Figure 1) indicates the different relative value for investors in face of different outcome. As seen from Figure 1, the corresponding absolute amount of value in the result of loss is larger than that of the result of win. The sensitivity of win and loss are also not equal, investors are more sensitive to loss when the amount of loss is low and the value of win is lower when the profit is not very large, which shows the aversion to loss in investment. Moreover, the larger the amount of loss, the lower the sensitivity. The feeling of loss often much more intensity than win in investment ( $\mathrm{Li}, 2012)$. 


\begin{tabular}{|c|c|c|c|c|}
\hline \multirow[t]{2}{*}{ Behavioral psychology } & \multirow[t]{2}{*}{ Questions } & \multirow[t]{2}{*}{ Options } & \multicolumn{2}{|l|}{ Proportion } \\
\hline & & & Ordinary investors & Institutional investors \\
\hline \multirow[t]{4}{*}{ Conservative bias } & \multirow{2}{*}{$\begin{array}{l}\text { When the stocks with ordinary } \\
\text { performance suddenly } \\
\text { receive excessive returns, } \\
\text { which option would you } \\
\text { prefer? }\end{array}$} & $\begin{array}{l}\text { A. I will sell the stocks at } \\
\text { opportune time. }\end{array}$ & $61.99 \%$ & $70.82 \%$ \\
\hline & & $\begin{array}{l}\text { B. I will buy the stocks } \\
\text { additionally. }\end{array}$ & $39.57 \%$ & $29.16 \%$ \\
\hline & \multirow[t]{2}{*}{$\begin{array}{l}\text { In face of new information, } \\
\text { which option would you } \\
\text { prefer? }\end{array}$} & $\begin{array}{l}\text { A. Further confirmation is } \\
\text { needed to make final } \\
\text { decision. }\end{array}$ & $42 \%$ & $58.33 \%$ \\
\hline & & $\begin{array}{l}\text { B. I will make use of the } \\
\text { new information immediately. }\end{array}$ & $21.33 \%$ & $8.33 \%$ \\
\hline \multirow[t]{7}{*}{ Over confidence } & \multirow[t]{4}{*}{$\begin{array}{l}\text { How do you consider about } \\
\text { the correctness of your own } \\
\text { judgment? }\end{array}$} & $\begin{array}{l}\text { A. Generally correct and I } \\
\text { can get higher return from my } \\
\text { own judgment. }\end{array}$ & $20.86 \%$ & $52 \%$ \\
\hline & & $\begin{array}{l}\text { B. Generally correct while I } \\
\text { cannot grasp it appropriately. }\end{array}$ & $50 \%$ & $40 \%$ \\
\hline & & C. Not sure. & $22.18 \%$ & $8 \%$ \\
\hline & & D. Usually Wrong. & $6.95 \%$ & $0 \%$ \\
\hline & \multirow{3}{*}{$\begin{array}{l}\text { Do you consider yourself as } \\
\text { talented people in } \\
\text { investment? }\end{array}$} & A. $\quad$ Yes, I think so. & $26.91 \%$ & $52 \%$ \\
\hline & & $\begin{array}{l}\text { B. Yes, while lam just } \\
\text { general talented one. }\end{array}$ & $52.15 \%$ & $44 \%$ \\
\hline & & \begin{tabular}{|ll} 
C. No, I don't think so. \\
\end{tabular} & $20.93 \%$ & $4 \%$ \\
\hline \multirow[t]{5}{*}{ Self-attribution bias } & \multirow{3}{*}{$\begin{array}{l}\text { When contradiction exists } \\
\text { between the fact and your } \\
\text { own judgment, which option } \\
\text { would you prefer? }\end{array}$} & $\begin{array}{l}\text { A. I think more time is } \\
\text { needed to further examine it. }\end{array}$ & $58.27 \%$ & $64 \%$ \\
\hline & & \begin{tabular}{|l} 
B. I will insist the original \\
judgment.
\end{tabular} & $22.18 \%$ & $25 \%$ \\
\hline & & $\begin{array}{l}\text { C. I will admit the mistake } \\
\text { of original judgment. }\end{array}$ & $19.53 \%$ & $11 \%$ \\
\hline & \multirow[t]{2}{*}{$\begin{array}{l}\text { If your judgment is consistent } \\
\text { with the fact, which option } \\
\text { would you prefer? }\end{array}$} & $\begin{array}{l}\text { A. It can be attributed to } \\
\text { accidental factors or there is } \\
\text { no clear attribution. }\end{array}$ & $63.53 \%$ & $28 \%$ \\
\hline & & $\begin{array}{l}\text { B. It should be attributed to } \\
\text { my ability of judgment. }\end{array}$ & $36.45 \%$ & $72 \%$ \\
\hline \multirow[t]{8}{*}{ Loss aversion } & \multirow{2}{*}{$\begin{array}{l}\text { Would you want to take part } \\
\text { in the gamble that you can } \\
\text { win } \$ 200 \text { and loss } \$ 100 \text { at } \\
\text { equal possibilities? }\end{array}$} & A. Yes, I want to. & $42.86 \%$ & $37.83 \%$ \\
\hline & & B. No, I don't want to. & $57.14 \%$ & $62.17 \%$ \\
\hline & \multirow{2}{*}{$\begin{array}{l}\text { If the repeat number of the } \\
\text { gamble increase to } 100 \text { times }\end{array}$} & A. Yes, I want to. & $88.92 \%$ & $91.89 \%$ \\
\hline & & B. No, I don't want to. & $11.08 \%$ & $8.11 \%$ \\
\hline & \multirow{2}{*}{$\begin{array}{l}\text { If the bet of the gamble is to } \\
\text { win and loss } \$ 100\end{array}$} & A. Accept the gamble & $35.63 \%$ & $32.43 \%$ \\
\hline & & B. Not accept the game & $64.37 \%$ & $67.57 \%$ \\
\hline & \multirow[t]{2}{*}{ If the bet increase to $\$ 10000$} & A. Accept the gamble & $18.94 \%$ & $18.91 \%$ \\
\hline & & B. Not accept the game & $81.06 \%$ & $81.09 \%$ \\
\hline
\end{tabular}

\section{CONCLUSION}

The paper has reviewed the literatures associated with behavioral psychology such as heuristics biases, including representativeness, availability and anchoring, and cognitive bias, which consists of over-confidence, over-reaction and herd effect. These psychology characteristics can provide explanations and solutions to the market anomalies to some extent.

The paper also studies the investment psychology of Chinese investors based on questionnaire. As seen from the above analysis, investors, especially institutional investors, in China show the irrational characteristic in making investment decision. Conservative bias, over-confidence, self-attribution bias and loss aversion are four main psychology biases according to the research. These biases are more obvious among institutional investors, which mean that the psychology biases cannot be improved or eliminated by studying and accumulating experiences.

www.journals.cz
Behavioral Finance is an exciting and interesting new field in terms of stock market research. The evidence of behavioral finance theory helps us understand behavioral psychology deeply and give more insight into stock market anomalies and investment strategy selection.

\section{REFERENCES}

Andreassen, P. B., \& Kraus, S. J. (1990). Judgmental extrapolation and the salience of change. Journal of Forecasting, 9, 347-372. http://dx.doi.org/10.1002/for.3980090405

Bondt, D., WFM, \& Thaler, R. H. (1985). Does the stock market overreact? Journal of Finance, 40, 793-805. http://dx.doi.org/ $10.2307 / 2327804$

Bondt, D. (1998). A portrait of the individual investor. European Economic Review, 42, 831-844.

Bondt, D., WFM \& Thaler, R. H. (1995). Financial decision making in markets and firms: A behavioral perspective, in Robert A., Jarrow, V. M., \& Ziemba (eds) W. Z.: Finance, Handbooks in Operations Research and Management. Science, 9, 385-410. 


\section{A STUDY OF THE INVESTMENT BEHAVIOR BASED ON BEHAVIORAL FINANCE}

Barberis, N., \& Huang, M. (2001). Mental accounting, loss aversion, and individual stock returns. Journal of Finance, 56, 1247-92. http://dx.doi.org/10.1111/0022-1082.00367

Barberis, N., Huang, M., \& Santos, J. (2001). Prospect theory and asset prices. Quarterly Journal of Economics, 141, 1-53. http://dx.doi.org/10.1162/003355301556310

Bernardo, A., \& Welch, I. (2001). On the evolution of overconfidence and entrepreneurs. Journal of Economics and Management Strategy, 10, 301-30. http://dx.doi.org/10.1162/105864001316907964

Dong, L. (2003). Wǒguó gǔpiào shìchăng tóuzī zhě liùzhǒng fēi líxìng xīnli yánjiū [A study of six irrational psychologies of investors in Chinese stock market]. Modern Management Science, 11.

Edwards, W. (1968). Conservatism in human information processing in B. Kleinmutz, ed.: Formal Representation of Human Judgment. Wiley, New York. http://dx.doi.org/10.1017/CBO9780511809477.026

Ellouz, S. (2011). Survey of the Phenomenon of Over-reaction and Under-reaction on French Stock Market. The IUP Journal of Behavioral Finance, 8(2).

Fischhoff, B., Slovic, P., \& Lichtenstein, S. (1978). Fault trees: Sensitivity of estimated failure probabilities to problem representation. Journal of Experimental Psychology, 4, 330-334.

Grether, D.M. (1992). Testing Bayes rule and the representativeness heuristic: Some experimental evidence. Journal of Economic Behavior and Organization, 17, 31-57. http://dx.doi.org/ 10.1016/0167-2681(92)90078-P

Grinblatt, M., \& Han, B. (2005). Prospect theory, mental accounting, and momentum. Journal of FinancialEconomics, 78, 311-39. http://dx.doi.org/10.1016/j.jfineco.2004.10.006

Hirshleifer, D. (2001). Investor Psychology and Asset Pricing. The Journal of Finance, 6(4). http://dx.doi.org/10.2139/ssrn.265132

Jones, B. (2012). Behavioral Finance 2.0. The Journal of Portfolio Management, 2.

Kahneman, D., \& Mark, W. (1998). Ripe, Aspects of investo psychology: Beliefs, preferences, and biases Investments advisors should know about. Journal of Portfolio Management, 24(4)

Lakonishok, J. (1992). Sectional trading on stock prices. Journal of Financial Economics, 32, 23-43.

Liu, C. (2006). Jīyú xíngwéi jīnróng xúe dè zhōngguó zhèngquàn fēnxī shī xíngwéi yánjiū [Research on Behavioral of Chinese Security Analysts Based on Behavioral Finance]. Available from China National Knowledge Internet.

Lovric, M., Kaymak, U., \& Spronk, J. (2008). A Conceptual Model of Investor Behavior. Retrieved from http://hdl.handle.net/1765/12468. http://dx.doi.org/10.1049/PBCE071E_ch13

Li, J. (2012). Jīyú xíngwéi jīnróng xúe dè gǔpiào shìchăng tóuzī zhě xíngwéi yánjiū [The Study of Security Market Behavior Based On Behavioral Finance]. Available from China National Knowledge Internet.

Li, S. J. (2012). Jīyú xíngwéi jīnróng xúe dè gèrén tóuzī xīnlī xíngwéi yánjiū [The Study of Investor Psychology Based On Behavioral Finance]. Available from China National Knowledge Internet.

Matthew, V. (2011). The Potential Contributions of Behaviora Finance to Post Keynesian and Institutionalist Finance Theories. Journal of Post Keynesian Economics, 33(4).

Patrick, R., \& Charles, G. L. (2011). Behavioral Finance and Post Keynesian- Institutionalist Theories of Financial Markets. Journal of Post Keynesian Economics, 33(4).

Rabin, M. (1999). Risk aversion and expected-utility theory: A Calibration Therorem. Cambridge University Press, Cambridge. http://dx.doi.org/10.1111/1468-0262.00158

Russell, J. (2000). Fuller, Behavioral finance and the sources of alpha. CFA.

Samuelson, P. A. (1963). Risk and Uncertainty : A Fallacy of Large Numbers, 108.

Shiller, R. J. (1984). Stock prices and social dynamics. Brookings Papers on Economic Activity, 457-498. http://dx.doi.org/10.2307/ 2534436

www.journals.cz
Scharfstein, D., \& Jeremy, S. (1990). Herding behavior and investment. American Economic Review, 80, 465-479.

Sekaran, U. (2003). Research methods for business: A skill building approach, Course Smart, India.

Shefrin, H. (2000). Beyond greed and fear: understanding behavioral finance and the psychology of investing. Harvard Business School Press, Boston, USA.

Shiller, R. (2001). The Irrationality of Markets. Journal of Psychology and Financial Markets, 3 (2), 87-93. http://dx.doi.org/10.1207/ S15327760JPFM0302_03

Scheinkman, J. A., \& Xiong, W. (2003). Overconfidence, short-sale constraints, and bubbles. Journal of Political Economy, 111, 1183219

Sent, E. (2004). Behavioral Economics: How Psychology Made Its (Limited) Way Back into Economics. History of Political Economy, 36(4), 735-760. http://dx.doi.org/10.1215/00182702-36-4-735

Subrahmanyam, A. (2007). Behavioral Finance: A Review and Synthesis. European Finance Management, 14(1), 12-29. http://dx.doi.org/10.1111/j.1468-036X.2007.00415.x

Tversky, A., \& Kahneman, D. (1974). Judgment under uncertainty: Heuristics and Biases.Science, 185, 1124-1131. http://dx.doi.org/ 10.1126/science.185.4157.1124

Trivers, R. (1991). Deceit and self-deception, in Robinson, R., \& Tiger, L. eds.: Man and Beast Revisited. Smithsonian Press, Washington DC.

Trivers, R. (1985). Social Evolution. Benjamin/Cummings, Menlo Park.

Wu, L. (2004). Jīyú xíngwéi jīnróng xúe dè wǒguó zhèngquàn tóuzī zhě xíngwéi yánjiū [The Study of Investment Behavior Based on Behavioral Finance Theory]. Available from China National Knowledge Internet. 